\title{
Analisis Epidemiologi Kasus Hipofungsi Ovarium pada Sapi Potong di Kabupaten Jepara
}

\section{Epidemiological Analysis of Ovarium Hypofunction in Beef Cattle in Jepara Regency}

\author{
Aldi Salman ${ }^{1}$, Surya Agus Prihatno ${ }^{2 *}$, Bambang Sumiarto ${ }^{3}$ \\ ${ }^{1}$ Dinas Peternakan dan Kesehatan Hewan, Provinsi Jawa Tengah, Jalan Gatot Subroto, Ungaran \\ ${ }^{2}$ Departemen Reproduksi dan Kebidanan, Fakultas Kedokteran Hewan, Universitas Gadjah Mada \\ ${ }^{3}$ Departemen Kesehatan Masyarakat Veteriner, Fakultas Kedokteran Hewan, \\ Universitas Gadjah Mada \\ *Corresponding author, email: prihatno@ugm.ac.id
}

Naskah diterima: 10 Juni 2020, direvisi: 7 November 2020, disetujui: 8 Januari 2021

\begin{abstract}
Ovarian hypofunction is the highest incidence of reproductive disorders in Central Java, breeders losses due to the long calving interval and increased maintenance costs. Feed quality is considered to be a cause of ovarian hypofunction, but there are also other factors that cause disease. The purpose of this study was to determine the prevalence and risk factors for ovarian hypofunction in beef cattle, as well as a model for predicting ovarian hypofunction in Jepara Regency. A total of 304 beef cow from 176 breeders were selected by formal random sampling in 14 villages in 7 sub-districts with multiple stages. Anamnesis was conducted to farmers and rectal examination of beef cow to determine the reproductive status, and questionnaires for animal husbandry and individual animals level. The results showed prevalence of ovarian hypofunction $8.88 \%$ and risk factors that have a relationship are frequency of supplementary feed $(\mathrm{OR}=12.77)$, ownership of one animal $(\mathrm{OR}=0.34)$, main feed $(\mathrm{OR}=9.59)$, breed type $(\mathrm{OR}=0.37)$, cows age $(\mathrm{OR}=0.33)$, lactation status $(\mathrm{OR}=0.07)$ and calf weaning time $(\mathrm{OR}=0.03)$. The disease model at livestock level is $\mathrm{Ln} \mathrm{P} / 1-\mathrm{P}=5,71-3,19 \mathrm{xSAPH}-1,83 \mathrm{xSTLAK}$ - 0,99xJNTR and at farm level is Ln P / 1-P = 1,21 + 1,81xPKUT + 1,74xPKTB - 1,33xPUNYA1.
\end{abstract}

Keywords : beef cows; disease model; ovarian hypofunction; prevalence; risk factor

\begin{abstract}
Abstrak
Hipofungsi ovarium menjadi kasus gangguan reproduksi yang memiliki angka kejadian paling tinggi di Jawa Tengah, dengan kerugian peternak karena panjangnya Calving Interval dan biaya pengobatan yang tinggi. Kualitas pakan seringkali dianggap menjadi menjadi penyebab hipofungsi ovarium, tetapi juga terdapat faktor lain yang mengakibatkan munculnya penyakit. Penelitian bertujuan untuk mengetahui prevalensi dan faktor risiko hipofungsi ovarium pada sapi potong, serta model untuk memprediksi penyakit hipofungsi ovarium di Kabupaten Jepara. Sapi betina produktif sebanyak 304 ekor sampel dari 176 peternak dipilih secara formal random sampling pada 14 desa di 7 kecamatan dengan tahapan ganda. Dilakukan anamnesis pada peternak dan pemeriksaan sapi secara per rektal untuk mengetahui status reproduksi, serta kuesioner untuk tingkat peternakan dan individu ternak. Hasil penelitian menunjukkan prevalensi hipofungsi ovarium $8,88 \%$ dan faktor risiko yang mempunyai hubungan adalah frekuensi pakan tambahan $(\mathrm{OR}=12,77)$ dan pakan utama $(\mathrm{OR}=9,59)$. Variabel yang menurunkan hipofungsi ovarium adalah jenis ternak ( $\mathrm{OR}=0,37)$, kepemilikan ternak satu $(\mathrm{OR}=0,34)$, umur ternak $(\mathrm{OR}=0,32)$, status laktasi $(\mathrm{OR}=0,07)$ dan umur sapih $(\mathrm{OR}=0,03)$. Model persamaan pada tingkat ternak adalah Ln P/1-P = 5,71 - 3,19xSAPH - 1,83xSTLAK - 0,99xJNTR. Model persamaan pada tingkat peternakan adalah $\mathrm{Ln} \mathrm{P} / 1-\mathrm{P}=1,21+1,81 \times \mathrm{xKUT}+1,74 x \mathrm{PKTB}-1,33 \times \mathrm{xUNYA} 1$.
\end{abstract}

Kata kunci : faktor risiko; hipofungsi ovarium; model penyakit; prevalensi; sapi potong 


\section{Pendahuluan}

Kesehatan hewan memiliki peran penting dalam dukungan keberhasilan peningkatan populasi kaitannya dengan penanganan gangguan reproduksi. Tingkat gangguan reproduksi pada ternak sapi betina produktif di Indonesia masih cukup tinggi, dengan prevalensi yang bervariasi antara 11\% hingga 57\% (Prihatno et al., 2015, Budiyanto et al., 2016, Anshori et al., 2017, Oktarianti, 2018, Putri et al. 2019). Kerugian ekonomi akibat gangguan reproduksi secara umum sebagai akibat meningkatnya pengeluaran biaya pengobatan dan operasional pemeliharaan karena jarak antar kelahiran yang lebih panjang.

Rendahnya kualitas pakan seringkali dianggap menjadi penyebab hipofungsi ovarium, tetapi kemungkinan terdapat faktor lain yang mengakibatkan munculnya penyakit, sehingga perlu disidik faktor-faktor yang memengaruhi munculnya hipofungsi ovarium pada ternak sapi potong. Penelitian ini bertujuan untuk mengetahui prevalensi dan mengidentifikasi faktor risiko yang berpengaruh terhadap hipofungsi ovarium pada sapi potong di Kabupaten Jepara, serta mendapat model kejadian hipofungsi ovarium pada tingkat peternakan dan ternak. Manfaat penelitian ini ialah mengidentifikasi faktor risiko yang memengaruhi kejadian penyakit sehingga dapat digunakan untuk dasar dalam penyusunan program pencegahan penyakit.

\section{Materi dan Metode}

Penelitian ini menggunakan kajian lintas seksional dengan metode sampling tahapan ganda untuk penentuan status reproduksi ternak. Populasi target adalah semua ternak yang dimiliki oleh peternak terpilih pada 14 desa yang terpilih secara acak di Kabupaten Jepara. Pemilihan peternakan dengan metode pengambilan sampel sacara rambang sederhana. Pemilihan sampel ternak pada peternakan diambil secara kluster dengan asumsi kepemilikan empat ekor per peternak. Faktor risiko didapat melalui pengamatan langsung dan wawancara dengan peternak untuk mengisi kuesioner yang telah disediakan.

Jumlah sampel dihitung menggunakan rumus besaran sampel (Martin et al., 1987), dengan prevalensi hipofungsi ovarium sebesar 19,32\%
(Rosadi et al., 2018) dan tingkat kepercayaan 95\% serta galat 5\% didapat jumlah sampel $n=\frac{4 \times 0,19 \times 0,81}{0,05^{2}}=$ $246,24 \approx 246$ ekor.

Perhitungan Design Effect (DE) dilakukan untuk mengurangi bias, melalui perhitungan variansi antar peternak $\left(\mathrm{S}_{1}^{2}\right)$ dan variansi dalam peternak $\left(\mathrm{S}_{2}^{2}\right)$ pada prevalensi yang sama dan $\rho=0,05$, maka perhitungan DE dan jumlah sampel adalah sebagai berikut:

$\mathrm{S}^{2}=\mathrm{P} \times \mathrm{Q}=0,19 \times 0,81=0,1539$

$\mathrm{S}_{1}^{2}=\rho \times \mathrm{S}^{2}=0,05 \times 0,1539=0,007695$

$\mathrm{S}_{2}{ }^{2}=\mathrm{S}^{2}-\mathrm{S}_{1}{ }^{2}=0,1539-0,007695=0,146205$

$\mathrm{n}_{\mathrm{p}}=\left[\frac{S_{2}{ }^{2}}{S_{1}{ }^{2}}\right]^{1 / 2}=\left[\frac{0,146205}{0,007695}\right]^{1 / 2}=4,36 \approx 4$ ekor per peternak

$\mathrm{DE}=1+\left(\mathrm{n}_{\mathrm{p}}-1\right) \rho=1+(4,36-1) 0,05=1,17$

$\mathrm{n}_{\mathrm{pps}}=\mathrm{n} \times \mathrm{DE}=246,24 \times 1,17=287,59 \approx 288$ ekor

Dengan jumlah sampel yang akan diambil sebanyak 288 ekor dan jumlah sampel per peternakan adalah 4 ekor per peternakan, sampel peternakan yang diambil adalah 72 peternakan.

Jumlah Desa yang dipilih menjadi lokasi penelitian dihitung menggunakan metode deteksi penyakit dengan prevalensi yang sama dan jumlah desa di Kabupaten Jepara (N) adalah 195 desa serta tingkat kepercayaan (a) $=95 \%$, maka didapat jumlah desa sampling adalah:

$$
\begin{aligned}
\mathrm{D}= & \mathrm{P} \times \mathrm{N}=0,19 \times 195=37,05 \\
\mathrm{n}= & {\left[1-(1-\mathrm{a})^{1 / \mathrm{D}}\right][\mathrm{N}-(\mathrm{D}-1) / 2] } \\
\mathrm{n}= & {\left[1-(1-0,95)^{1 / 37,05}\right][195-(37,05-1) / 2]=13,74 \approx } \\
& 14 \text { desa }
\end{aligned}
$$

Pemilihan lokasi menggunakan tahapan ganda secara probability proportional to size (PPS) menggunakan data populasi ternak dari Badan Pusat Statistik Kabupaten Jepara Tahun 2018 dimana 14 Kelurahan/Desa dipilih secara random dari 7 (tujuh) Kecamatan dengan populasi padat ternak.

Analisis bivariate dilakukan dengan menghitung prevalensi yang didapat dengan membandingkan proporsi sapi betina terdiagnosis hipofungsi ovarium dan jumlah sampel. Faktor risiko diolah menggunakan IBM SPSS Statistics 22.0 untuk diukur adanya asosiasi dengan menggunakan uji chi-square $(\chi 2)$ dan kekuatan asosiasi dengan rasio ganjil (odd ratio/OR). Analisis multivariate digunakan untuk mendapat model regresi logistik yang menerangkan hu- 
bungan antara kejadian penyakit dengan beberapa faktor risiko yang berpengaruh. Model dibangun untuk mengetahui peluang kejadian hipofungsi ovarium dari beberapa faktor risiko yang teridentifikasi. Model diolah menggunakan IBM SPSS Statistics 22.0 lalu dihitung sensitifitas dan spesifisitas model.

\section{Hasil dan Pembahasan}

Penentuan sampel menggunakan metode stratified random sampling agar didapat gambaran kondisi populasi yang sebenarnya. Dari hasil identifikasi status reproduksi pada tingkat individu ternak dapat dilihat pada Tabel 1 dan diketahui prevalensi kasus hipofungsi ovarium di Kabupaten Jepara adalah sebesar 8,9\%. Sapi terdiagnosa bunting $39,8 \%$, post partus $16,8 \%$, gangguan reproduksi $29,3 \%$ dan $14,1 \%$ sudah dikawinkan tetapi belum dapat ditentukan kebuntingannya. Gangguan reproduksi yang ditemukan yaitu kawin berulang (repeat breeding), hipofungsi ovarium, birahi tenang (silent heat), keterlambatan pubertas (delayed puberty), endometritis, sista luteal dan abortus.

Tabel 1. Diagnosa hasil pemeriksaan reproduksi pada individu ternak

\begin{tabular}{lcc}
\hline Diagnosa & Jumlah (ekor) & Persentase \\
\hline Bunting & 121 & $39,8 \%$ \\
Post partus & 51 & $16,8 \%$ \\
Repeat breeding & 28 & $9,2 \%$ \\
Hipofungsi ovarium & 27 & $8,9 \%$ \\
Fase folikuler & 25 & $8,2 \%$ \\
Silent heat & 24 & $7,9 \%$ \\
Fase luteal & 18 & $5,9 \%$ \\
Delayed puberty & 5 & $1,6 \%$ \\
Endometritis & 3 & $1,0 \%$ \\
Sista luteal & 1 & $0,3 \%$ \\
Abortus & 1 & $0,3 \%$ \\
\hline \multicolumn{1}{c}{ Total } & 304 & \\
\hline
\end{tabular}

Gangguan reproduksi ditemukan pada 29,3\% sampel sapi betina produktif di Kabupaten Jepara dengan prevalensi hipofungsi ovarium sebesar $8,88 \%$ seperti terlihat pada Tabel 1 . Hipofungsi ovarium bukan kasus gangguan reproduksi yang paling banyak ditemukan, prevalensi repeat breeding 9,2\% paling tinggidibandingkandiagnosa gangguan reproduksi lain. Rendahnya prevalensi hipofungsi ovarium kemungkinan disebabkan karena kegiatan penanggulangan reproduksi yang optimal dilaksanakan sejak tahun 2015 di Provinsi Jawa Tengah. Perbaikan dalam praktik pemberian pakan, tata laksana perkandangan, dan manajemen kesehatan secara terus menerus akan menurunkan kejadian gangguan reproduksi, termasuk hipofungsi ovarium (Khan et al., 2016). Menurunnya kejadian hipofungsi ovarium juga dapat disebabkan karena musim saat penentuan status reproduksi ternak, musim hujan cenderung meningkatkan performa reproduksi karena ketersediaan hijauan mencukupi untuk kebutuhan nutrisi ternak (Liu et al., 2018).

Analisis bivariat dengan melakukan tabulasi silang antara variabel peternakan dan ternak dengan variabel hipofungsi ovarium. Hasil analisis bivariat pada Tabel 2 menunjukkan faktor risiko yang mempunyai hubungan signifikan $(p<0,05)$ dan kekuatan hubungan (OR) tinggi terhadap hipofungsi ovarium pada sapi potong di Kabupaten Jepara secara berurutan adalah Frekuensi Pakan Tambahan $(\mathrm{p}=0,00 ; \mathrm{OR}=12,8)$, Pakan Utama $(\mathrm{p}=0,00 ; \quad \mathrm{OR}=9,6), \quad$ Jenis Ternak $(\mathrm{p}=0,02$; $\mathrm{OR}=0,37)$, Jumlah Ternak $1(\mathrm{p}=0,01 ; \mathrm{OR}=0,34)$, Umur Ternak $(\mathrm{p}=0,00 ; \mathrm{OR}=0,32)$, Status Laktasi $(p=0,00 ; O R=0,07)$, dan Umur Sapih $(p=0,00$; $\mathrm{OR}=0,03)$.

Faktor risiko yang yang tidak mempunyai hubungan dengan hipofungsi ovarium $(p>0,05)$ adalah variabel Mengerti SOP IB $(p=0,06)$, Jumlah Ternak 2-4 $(p=0,10)$, Jumlah Kelahiran $(p=0,11)$, Rekording $(p=0,15)$, Jenis Kandang $(p=0,16)$, Jumlah ternak $>4(p=0,22)$, Lantai Kandang $(\mathrm{p}=0,26)$, Alas Kandang $(\mathrm{p}=0,35)$, Lama Birahi $(p=0,73)$, Sumber Cahaya Kandang $(p=0,78)$, Jarak laporan dan kawin $(p=0,82)$, Sumber Pengetahuan Peternak $(p=0,92)$ dan Pencahayaan Kandang ( $p=0,92)$.

Frekuensi pakan tambahan menjadi variabel yang paling memengaruhi kejadian hipofungsi ovarium pada sapi potong di Kabupaten Jepara, sapi milik peternak yang pakan tambahan diberikan tidak tentu memiliki risiko 12,7 kali mengalami hipofungsi ovarium dibanding yang frekuensi pakan tambahannya rutin. Frekuensi pemberian pakan tambahan menentukan kondisi tubuh induk dan performa reproduksi, semakin sering dan rutin 
Tabel 2. Analisis bivariat terhadap variabel peternakan dan ternak

\begin{tabular}{|c|c|c|c|c|c|}
\hline Variabel & Hipofungsi & Non Hipofungsi & Chi Square & p-value & OR \\
\hline $\begin{array}{l}\text { Umur Sapih } \\
-\quad<6 \text { bulan } \\
-\geq 6 \text { bulan }\end{array}$ & $\begin{array}{c}3 \\
24\end{array}$ & $\begin{array}{c}228 \\
49\end{array}$ & $68,35^{*}$ & 0,00 & 0,03 \\
\hline $\begin{array}{l}\text { Pakan Utama } \\
\text { - Jerami } \\
\text { - } \text { Rumput }\end{array}$ & $\begin{array}{c}19 \\
8\end{array}$ & $\begin{array}{c}55 \\
222\end{array}$ & $34,09 *$ & 0,00 & 9,59 \\
\hline $\begin{array}{l}\text { Status Laktasi } \\
\text { - } \text { tidak nyusui } \\
\text { - menyusui }\end{array}$ & $\begin{array}{c}2 \\
25\end{array}$ & $\begin{array}{l}147 \\
130\end{array}$ & $20,51 *$ & 0,00 & 0,07 \\
\hline $\begin{array}{l}\text { Frekuensi Pakan Tambahan } \\
\text { - Tidak Tentu } \\
\text { - Rutin }\end{array}$ & $\begin{array}{c}25 \\
2\end{array}$ & $\begin{array}{l}137 \\
140\end{array}$ & $18,39 *$ & 0,00 & 12,77 \\
\hline $\begin{array}{l}\text { Umur Ternak } \\
\text { - muda } \\
\text { - tua }\end{array}$ & $\begin{array}{l}12 \\
15\end{array}$ & $\begin{array}{c}198 \\
79\end{array}$ & $8,42 *$ & 0,00 & 0,32 \\
\hline $\begin{array}{l}\text { Jml Ternak } 1 \\
\text { - tidak } \\
\text { - ya }\end{array}$ & $\begin{array}{c}18 \\
9\end{array}$ & $\begin{array}{c}237 \\
40\end{array}$ & $6,49 *$ & 0,01 & 0,34 \\
\hline $\begin{array}{l}\text { Jenis Ternak } \\
\text { - Lokal } \\
\text { - } \text { Silangan }\end{array}$ & $\begin{array}{c}18 \\
9\end{array}$ & $\begin{array}{c}234 \\
43\end{array}$ & $5,50^{*}$ & 0,02 & 0,37 \\
\hline $\begin{array}{l}\text { Mengerti SOP IB } \\
-\quad \text { Tidak ngerti } \\
\text { - } \quad \text { Mengerti dan paham }\end{array}$ & $\begin{array}{c}2 \\
25\end{array}$ & $\begin{array}{c}5 \\
272\end{array}$ & 3,43 & 0,06 & - \\
\hline $\begin{array}{l}\text { Jml Ternak 2-4 } \\
- \text { tidak } \\
- \text { ya }\end{array}$ & $\begin{array}{c}9 \\
18\end{array}$ & $\begin{array}{c}55 \\
222\end{array}$ & 2,69 & 0,10 & - \\
\hline $\begin{array}{l}\text { Jumlah Kelahiran } \\
-\quad<2 \text { kali } \\
-\quad \geq 2 \text { kali }\end{array}$ & $\begin{array}{l}12 \\
15\end{array}$ & $\begin{array}{l}167 \\
110\end{array}$ & 2,55 & 0,11 & - \\
\hline $\begin{array}{l}\text { Rekording } \\
\text { - tidak ada } \\
\text { - ada }\end{array}$ & $\begin{array}{c}2 \\
25\end{array}$ & $\begin{array}{c}7 \\
270\end{array}$ & 2,04 & 0,15 & - \\
\hline $\begin{array}{l}\text { Jenis Kandang } \\
\text { - kecil } \\
\text { - besar }\end{array}$ & $\begin{array}{c}3 \\
24\end{array}$ & $\begin{array}{c}63 \\
214\end{array}$ & 1,96 & 0,16 & - \\
\hline $\begin{array}{l}\text { Jml Ternak }>4 \\
\text { - tidak } \\
\text { - ya }\end{array}$ & $\begin{array}{c}27 \\
0\end{array}$ & $\begin{array}{c}262 \\
15\end{array}$ & 1,54 & 0,21 & - \\
\hline $\begin{array}{l}\text { Lantai Kandang } \\
\text { - Becek } \\
\text { - Kering }\end{array}$ & $\begin{array}{c}4 \\
23\end{array}$ & $\begin{array}{c}23 \\
254\end{array}$ & 1,29 & 0,26 & - \\
\hline $\begin{array}{l}\text { Alas Kandang } \\
\text { - Tanah } \\
\text { - Semen }\end{array}$ & $\begin{array}{l}12 \\
15\end{array}$ & $\begin{array}{l}149 \\
128\end{array}$ & 0,86 & 0,35 & - \\
\hline $\begin{array}{l}\text { Jarak laporan dan kawin } \\
-\quad<12 \text { jam } \\
-\quad \geq 12 \text { jam }\end{array}$ & $\begin{array}{c}26 \\
1\end{array}$ & $\begin{array}{c}264 \\
13\end{array}$ & 0,06 & 0,82 & - \\
\hline $\begin{array}{l}\text { Pencahayaan } \\
\text { - Gelap } \\
\text { - Terang }\end{array}$ & $\begin{array}{c}2 \\
25\end{array}$ & $\begin{array}{c}22 \\
255\end{array}$ & 0,01 & 0,92 & - \\
\hline $\begin{array}{l}\text { Sumber Pengetahuan } \\
\text { - Sendiri } \\
\text { - Suluh } / \text { drh } / \text { pv }\end{array}$ & $\begin{array}{c}2 \\
25\end{array}$ & $\begin{array}{c}22 \\
255\end{array}$ & 0,01 & 0,92 & - \\
\hline
\end{tabular}


diberikan maka pola metabolisme tubuh menjadi lebih seimbang. Pemberian pakan yang tidak teratur akan mengganggu keseimbangan energi dan menyebabkan inaktivasi ovarium (Winugroho, 2002; Wathes et al, 2007).

Pemberian jerami tanpa pengolahan sebagai pakan utama juga signifikan memberi pengaruh pada kasus hipofungsi ovarium, peternak yang menggunakan jerami sebagai pakan utama berisiko 9,6 kali mengalami hipofungsi ovarium dibanding peternak yang menggunakan rumput. Nilai nutrisi jerami yang rendah, bahkan setelah pengolahan, membuat jerami kurang bagus untuk digunakan sebagai pakan tunggal (Yanuartono et al., 2017). Hijauan seperti rumput gajah dan rumput odot memiliki protein yang tinggi, yaitu dalam kisaran $17-19 \%$ dan Total Digestable Nutrient mencapai 64,31\% sehingga mampu mencukupi kebutuhan nutrisi ternak, termasuk kebutuhan untuk sintesis hormon reproduksi (Purwawangsa dan Putera, 2014)

Pemeliharaan ternak sapi potong pada peternakan rakyat di Kabupaten Jepara didominasi oleh sapi lokal, khususnya sapi Peranakan Ongole. Pemilihan jenis sapi memengaruhi kejadian hipofungsi ovarium, sapi lokal menurunkan risiko hipofungsi ovarium sebesar 0,37 kali dibanding sapi silangan. Selain mudah beradaptasi dengan lingkungan dan pakan, sapi lokal jenis peranakan ongole memiliki performa reproduksi yang lebih baik daripada sapi persilangan. Sapi lokal masih menampakkan gejala birahi dan bunting meskipun berada pada Skor Kondisi Tubuh (SKT) yang tidak ideal (Luthfi et al., 2011; Yulyanto et al., 2014).

Rata-rata jumlah kepemilikan ternak di Kabupaten Jepara adalah 2,27 $\pm 1,05$ ekor per peternak. Uji chi-square $(\chi 2)$ memperlihatkan tidak ada pengaruh jumlah kepemilikan ternak pada kasus hipofungsi ovarium, tetapi ada hubungan antara peternak dengan kepemilikan tunggal dengan kejadian hipofungsi ovarium. Peternakan dengan populasi lebih dari satu ekor menurunkan kasus hipofungsi ovarium 0,34 kali dibandingkan peternakan dengan jumlah satu ekor. Jumlah kepemilikan sapi akan berpengaruh terhadap manajemen pemeliharaannya, peternak rakyat dengan kepemilikan rendah biasanya beternak sebagai sambilan dan ternak sebagai tabungan sehingga pemeliharaan menjadi tidak intensif dan menurunkan performa reproduksi ternaknya. Populasi yang sedikit pada awalnya dianggap baik karena pemeliharaan menjadi lebih mudah, tetapi pada peternakan berorientasi profit justru ketika populasi bertambah maka pengamatan terhadap ternak juga semakin meningkat sehingga kejadian penyakit lebih rendah (Grohn et al., 2000; Annisa et al., 2018).

Umur ternak ditentukan dengan melihat pergantian gigi seri pada sapi induk, sapi muda berumur di bawah 4 tahun ditandai dengan masih ada gigi susu yang belub berganti menjadi gigi seri. Umur ternak yang dipelihara juga memengaruhi kejadian hipofungsi ovarium, ternak muda menurunkan risiko sebesar 0,32 kali dibanding ternak tua sehingga ternak berusia tua memiliki risiko 3,13 kali mengalami hipofungsi ovarium daripada ternak muda. Ternak yang lebih muda memiliki kemampuan untuk menyerap nutrisi lebih baik daripada ternak yang lebih tua, juga dengan kemampuan regenerasi sel-sel. Performa reproduksi menurun seiring bertambahnya umur ternak dan jumlah kelahirannya (Motlagh et al., 2013).

Induk yang tidak menyusui pedet menurunkan risiko 0,07 kali mengalami hipofungsi ovarium dibanding induk yang menyusui. Induk yang menyusui setidaknya mengalami efek menyusu dan stres laktasi. Menyusui pedet secara signifikan menekan aktivitas ovarium pada induk sehingga status laktasi secara langsung akan memengaruhi kejadian hipofungsi ovarium pada sapi potong. Efek pedet yang mengisap pada puting adalah keluarnya endorfin, yang bekerja sebagai neurotransmiter di seluruh sistem saraf pusat, menyebabkan hambatan penghambatan pelepasan luteinizing hormon yang berfungsi dalam siklus estrus. Stres laktasi terjadi karena peningkatan kebutuhan nutrisi untuk metabolisme basal dan produksi susu, menyebabkan keseimbangan energi negatif dan mengganggu proses sintesis hormon reproduksi (Orihuela dan Galina, 2019; Brauner et al. 2009).

Peternak di Kabupaten Jepara menahan untuk tidak menyapih pedetnya lebih cepat untuk mendapatkan harga panen pedet yang lebih tinggi. Umur sapih secara signifikan memiliki asosiasi dengan kasus hipofungsi ovarium pada sapi potong. Induk yang pedetnya disapih sebelum 
berumur enam bulan menurunkan risiko kejadian hipofungsi ovarium 0,03 kali dibanding induk yang pedetnya disapih lebih dari enam bulan. Menyapih pedet lebih dari enam bulan memiliki risiko $37 \mathrm{kali}$ induk mengalami hipofungsi ovarium. Pedet yang disapih pada umur lebih dari lima bulan memiliki kondisi tubuh yang lebih baik dan menurunkan kebutuhan hijauan di awal periode pemeliharaan pedet, tetapi kondisi tubuh induk akan terus menurun seiring kebutuhan nutrisi pedet yang semakin tinggi. Dalam jangka panjang, kondisi tubuh yang menurun menyebabkan keseimbangan energi negatif dan berdampak pada performa reproduksi (Ciccioli et al., 2003; Wathes et al., 2007).

Analisis Regresi Logistik digunakan untuk menerangkan hubungan antara kejadian hipofungsi ovarium dengan beberapa faktor risiko yang berpengaruh. Pendekatan yang digunakan untuk hipofungsi ovarium merujuk pada penyakit non infeksius dengan model yang digunakan lebih banyak pada faktor peternak serta aktifitas fisik, pakan dan lingkungan ternak (Nianogo dan Arah, 2015). Regresi logistik dimulai dengan memasukkan seluruh variabel peternakan dan variabel individu ternak, kemudian diuji dengan satu P-value untuk mendapatkan model dengan akurasi terbaik. Sensitivitas dan spesifisitas model dihitung (Harrel, 2012).
Menggunakan variabel ternak, terdapat tiga variabel yang berpengaruh secara signifikan terhadap kasus hipofungsi ovarium, yaitu Umur Sapih Pedet (Pvalue $=0,00 ; \beta=-3,19$ ), Status Laktasi (Pvalue $=0,02 ; \beta=-1,83$ ) dan Jenis Ternak (Pvalue $=0,07 ; \beta=-0,99)$, seperti tampak pada Tabel 3.

Model persamaan yang dibentuk adalah sebagai berikut:

Ln P/1-P = 5,71 - 3,19xSAPH - 1,83xSTLAK - 0,99xJNTR

Peternak yang menyapih pedetnya kurang dari enam bulan, sapi betina yang tidak menyusui dan jenis indukan sapi potong lokal akan menurunkan peluang terjadinya hipofungsi ovarium. Perhitungan akurasi model didapat sensitivitas model $25,9 \%$ dan spesifisitas model 97,8\%, model hipofungsi ovarium dianggap cukup baik terutama untuk mendeteksi ternak yang tidak sakit sebagai ternak yang benar-benar yang tidak mengalami hipofungsi ovarium berdasarkan variabel individu ternak.

Menggunakan variabel peternakan, terdapat tiga variabel yang berpengaruh secara signifikan terhadap kasus hipofungsi ovarium, yaitu Pakan Utama (Pvalue $=0,00 ; \beta=1,81$ ), Frekuensi pemberian Pakan Tambahan (Pvalue $=0,03 ; \beta=1,74$ ) dan Kepemilikan Ternak Satu Ekor (Pvalue $=0,01$; $\beta=-1,33)$, seperti tampak pada Tabel 4 .

Tabel 3. Hasil Uji Signifikansi Multivariat pada Variabel Ternak

\begin{tabular}{llcccccc}
\hline & & B & S.E. & Wald & df & Sig. & OR \\
\hline Step 5 $^{\text {a }}$ & JNTR &,- 992 &, 547 & 3,283 & 1 & 0,070 & 0,371 \\
& STLAK & $-1,825$ &, 788 & 5,357 & 1 & 0,021 & 0,161 \\
& SAPH & $-3,198$ &, 647 & 24,422 & 1 & 0,000 & 0,041 \\
& Constant & 5,709 &, 890 & 41,133 & 1 & 0,000 & 301,539 \\
\hline
\end{tabular}

Variable(s) entered on step 1: JNTR, UMT, LBR, JRLK, PART, STLAK, SAPH.

Tabel 4. Hasil Uji Signifikansi Multivariat pada Variabel Peternak

\begin{tabular}{llcccccc}
\hline & & B & S.E. & Wald & df & Sig. & OR \\
\hline \multirow{2}{*}{ Step 16 } & PUNYA1 & $-1,331$ &, 507 & 6,889 & 1 & 0,009 & 0,264 \\
& PKUT & 1,813 &, 495 & 13,396 & 1 & 0,000 & 6,131 \\
& PKTB & 1,736 &, 793 & 4,801 & 1 & 0,028 & 5,677 \\
& Constant & 1,213 &, 295 & 16,886 & 1 & 0,000 & 3,364 \\
\hline
\end{tabular}

Variable(s) entered on step 1: BNGSRI, KEMBANG, PAKISAJI, MLONGGO, BATEALIT, KELING, PUNYA1, PUNYADIKIT, KDGKCL, CAHY, SBCH, LTKD, ALKD, PKUT, PKTB, RKD, SMBP, PRIB. 
Model persamaan yang dibentuk adalah sebagai berikut:

$\mathrm{LnP} / 1-\mathrm{P}=1,21+1,81 \times \mathrm{PKUT}+1,74 \times \mathrm{PKTB}-1,33 \times \mathrm{PUNYA} 1$

Peternak yang menggunakan jerami sebagai sumber pakan utama, tidak rutin memberikan pakan tambahan dan memelihara hanya satu ternak akan menaikkan peluang terjadinya hipofungsi ovarium. Perhitungan akurasi model didapat sensitivitas $66,7 \%$ dan spesifisitas $98,6 \%$. Akurasi model cukup baik untuk memprediksi hipofungsi ovarium karena sensitivitas dan spesifisitas di atas $60 \%$.

\section{Ucapan Terima kasih}

Penulis mengucapkan terima kasih kepada Dinas Ketahanan Pangan dan Pertanian Kabupaten Jepara atas data dan pendampingan yang diberikan, serta Program Rekognisi Tugas Akhir Tahun 2020 Universitas Gadjah Mada yang telah mendanai penelitian ini.

\section{Kesimpulan}

Prevalensi hipofungsi ovarium pada sapi potong $8,9 \%$ dan variabel yang mempunyai hubungan bermakna secara statistik $(p<0,05)$ dan meningkatkan hipofungsi ovarium adalah frekuensi pakan tambahan/PKTB $(\mathrm{OR}=12,77)$ dan pakan utama/PKUT $(\mathrm{OR}=9,59)$. Variabel yang menurunkan hipofungsi ovarium adalah jenis ternak/JNT $\quad(\mathrm{OR}=0,37), \quad$ kepemilikan ternak satu/PUNYA1 (OR=0,34), umur ternak/UMT $(\mathrm{OR}=0,32)$, status laktasi/STLAK $(\mathrm{OR}=0,07)$ dan umur sapih/SAPH (OR=0,03).

Model persamaan yang diperoleh pada tingkat ternak adalah Ln P/1-P = 5,709 - 3,198xSAPH 1,825xSTLAK - 0,992xJNTR. Model persamaan pada tingkat peternakan adalah $\mathrm{Ln} \mathrm{P} / 1-\mathrm{P}=1,213$ $+1,813 x$ PKUT $+1,736 x$ PKTB $-1,331 x$ PUNYA 1

\section{Daftar Pustaka}

Annisa, N.N., Roslizawaty, Hamdan, Iskandar, C.D., Ismail dan Siregar, T.N. (2018)., Peran Peternak Terhadap Keberhasilan Inseminasi Buatan Pada Sapi Di Kabupaten Asahan. JIMVET E-ISSN : 2540-9492.
Anshori, A., Nurhajati, T. and Utomo, B. (2017). Cases of Reproduction Disorder in Beef Cattle of Modo District, Lamongan in 2015. The Veterinary Medicine International Conference 2017 DOI 10.18502/kls. v3i6.1203.

Budiyanto, A., Tophianong, T.C., Triguntoro dan Dewi, H.K. (2016). Gangguan Reproduksi Sapi Bali pada Pola Pemeliharaan Semi Intensif di Daerah Sistem Integrasi SapiKelapa Sawit. Acta Veterinaria Indonesiana. Vol. 4, No. 1: 14-18.

Brauner, C.C., Pimentel, M.A. and Lemes, J.S. (2009). Postpartum reproductive performance of beef cows in moderate body condition submitted to estrus induction/ synchronization. Revista Brasileira de Zootecnia. v.38, n.1 p.99-103.

Ciccioli, N.H., Wettemann, R.P., Spicer, L.J., Lents, C.A., White, F.J. and Keisler, D.H. (2003). Influence of body condition at calving and postpartum nutrition on endocrine function and reproductive performance of primiparous beef cows. $J$. Anim. Sci. 81:3107-3120.

Grohn, Y.T. and Rajala-Schultz, P.J. (2000). Epidemiology of reproductive performance in dairy cow. Animal Reproduction Science. 60-61 605-614.

Harrell, F.E. (2012). Regression Modeling Strategies. Vanderbilt University: Tennessee, Amerika Serikat.

Khan, M.H., Manoj, K. and Pramod, S. (2016). Reproductive disorders in dairy cattle under semi-intensive system of rearing in NorthEastern India. Veterinary World. 9(5): 512518.

Liu, W.B., Peh, H.C., Wang, C.K., Mangwe, M.C., Chen, C.F. and Chiang, H.I. (2018). Effect of seasonal changes on fertility parameters of Holstein dairy cows in subtropical climate of Taiwan. Asian-Australas J Anim Sci. Vol. 31, No. 6:820-826.

Luthfi, M., Anggraeny, Y.N. dan Darminto. (2011). Perbedaan Performan Reproduksi Sapi PO dan Brahman Cross di Berbagai 
Lokasi di Jawa Tengah dan Jawa Timur. disampaikan pada Seminar Nasional Teknologi Peternakan dan Veteriner 2011

Martin, S.W., Meek, A.H. and Willeberg, P. (1987). Veterinary Epidemiology: Principles and Methods. Iowa State University Press: Amerika Serikat

Motlagh, M.K., Roohani, Z., Shahne, A.Z. and Moradi, M. (2013). Effects of age at calving, parity, year and season on reproductive performance of dairy cattle in Tehran and Qazvin Provinces, Iran, Res. Opin. Anim. Vet. Sci. 3(10)

Nianogo, R.A. and Arah, O.A. (2015). AgentBased Modeling of Noncommunicable Diseases: A Systematic Review. American Journal of Public Health. Vol 105, No. 3

Oktarianti, E. (2018). Reproductive Disorder in Cows: Data Analisys of UPSUS SIWAB in Lima Puluh Kota District, 2017. disampaikan pada 20th FAVA CONGRESS $\&$ The 15th KIVNAS PDHI, Bali Nov 1-3.

Orihuela, A. and Galina, C.S. (2019). Effects of Separation of Cows and Calves on Reproductive Performance and Animal Welfare in Tropical Beef Cattle. Animals. 9, 223.

Prihatno, S.A., Putro, P.P., Gustari, S., Kusumawati, A., Junaidi, A. dan Budiyanto, A. (2015). Kajian Epidemiologi Gangguan Reproduksi Saat/days Partum pada Sapi Perah di Kabupaten Sleman. disampaikan pada Inovasi veteriner dalam Riset dan Industri untuk Menjawab Tantangan Pasar, Fakultas Kedokteran Hewan Universitas Gadjah Mada Yogyakarta: FKH UGM

Purwawangsa, H. dan Putera, B.W. (2014). Pemanfaatan Lahan Tidur untuk Penggemukan Sapi. Risalah Kebijakan Pertanian dan Lingkungan, Vol. 1 No. 2, 92-96
Putri, S.H.T. dan Purnama, B.I. (2019). Identifikasi Gangguan Reproduksi Sapi Potong Dalam Mendukung Upsus Siwab Di Kecamatan Ampek Nagari Kabupaten Agam Tahun 2017. Prosiding Penyidikan Penyakit Hewan Rapat Teknis dan Pertemuan Ilmiah (RATEKPIL) dan Surveilans Kesehatan Hewan Tahun 2019

Rosadi, B., Sumarsono, T. dan Hoesni, F. (2018). Identifikasi Gangguan Reproduksi pada Ovarium Sapi Potong yang Mengalami Anestrus Postpartum Panjang. Jurnal Veteriner. Vol. 19 No. 3: 385-389

Wathes, D.C., Fenwick, M., Cheng, Z., Bourne, N., Llewellyn, S., Morris, D.G., Kenny, D., Murphy, J. and Fitzpatrick, R. (2007). Influence of negative energy balance on cyclicity and fertility in the high producing dairy cow. Theriogenology 68S S232-S241

Winugroho, M. (2002). Strategi Pemberian Pakan Tambahan untuk Memperbaiki Efisiensi Reproduksi Induk Sapi. Jurnal Litbang Pertanian. 21(1)

Yanuartono, Purnamaningsih, H., Indarjulianto, S. dan Nururrozi, A. (2017). Potensi jerami sebagai pakan ternak ruminansia, Jurnal Ilmu-Ilmu Peternakan. 27 (1): 40 - 62

Yulyanto, C.A., Susilawati, T. dan Ihsan, M.N. (2014). Penampilan reproduksi sapi Peranakan Ongole (PO) dan Sapi Peranakan Limousin di Kecamatan Sawo Kabupaten Ponorogo dan Kecamatan Tugu Kabupaten Trenggalek, Jurnal Ilmu-Ilmu Peternakan. 24 (2): $49-57$ 